\title{
A second generation of RT-PCR assay for detection of human immunodeficiency virus type 1 (HIV-1) infection
}

\author{
Andi Yasmon, ${ }^{1}$ Ni N. D. Fatmawati, ${ }^{2}$ Fera Ibrahim, ${ }^{1}$ Budiman Bela ${ }^{1}$ \\ ${ }^{1}$ Department of Microbiology, Faculty of Medicine, University of Indonesia, Jakarta, Indonesia \\ ${ }^{2}$ Department of Microbiology, Faculty of Medicine, University of Udayana, Bali, Indonesia
}

\begin{abstract}
Abstrak
Tujuan Diagnosis cepat dan spesifik seperti uji RT-PCR sangat diperlukan dalam usaha meminimalisasi penyebaran infeksi HIV-1. Oleh karena itu, dalam studi ini dikembangkan uji RT-PCR yang spesifik terhadap gen gag HIV-1 sebagai target diagnosis.

Metode Uji RT-PCR dievaluasi terhadap 46 spesimen yang diperoleh dari voluntary counseling and testing for HIV (VCT) di Rumah Sakit Umum Pmerintah (RSUP) Sanglah, Bali. Untuk mendapatkan sensitivitas dan spesifitas uji, hasil uji RT-PCR dibandingkan dengan hasil serologi yang umum digunakan di Indonesia.

Hasil Uji RT-PCR dapat mendeteksi 21dari 26 spesimen yang positif uji serologi dan memberikan 19 hasil uji negatif dari 20 spesimen yang negatif uji serologi. Satu spesimen menunjukkan hasil positif dengan RT-PCR tetapi negatif dengan uji serologi. Hasil tersebut kemungkinan menggambarkan hasil yang sebenarnya saat uji serologi tidak dapat mendeteksi infeksi HIV-1. Selain itu, lima spesimen yang positif uji serologi menunjukkan hasil negatif dengan RT-PCR yang diduga disebabkan oleh batas deteksi uji RT-PCR yang rendah.
\end{abstract}

Kesimpulan Uji PCR-RT yang dikembangkan dalam studi ini berpotensi digunakan sebagai uji alternatif untuk mendeteksi infeksi HIV-1 dengan 80.0\% sensitivitas dan 95.0\% spesifisitas. (Med J Indones 2010; 19:154-7)

\begin{abstract}
Aim A spesific and rapid diagnosis such as RT-PCR asay is the most needed to minimize transmission of HIV-1 infection. Therefore, in this study we developed the RT-PCR assay that was spesific against the gag gene of HIV-1.

Methods The developed RT-PCR assay was evaluated against 46 specimens that were obtained from voluntary counseling and testing for HIV (VCT) in Rumah Sakit Umum Pemerintah (RSUP) Sanglah, Bali. To get the sensitivity and specificity of RT-PCR assay, the results of assays were compared with the results of commercially serologic tests that were commonly used in Indonesia.

Results The RT-PCR assay could detect 21 of 26 serologic test-positive specimens and showed 19 negative results of 20 serologic test-negative specimens. There was one specimen that was positive in RT-PCR but negative in serologic assay, which might depict a true yield at particular condition when the serologic assay was unable to detect. Five serologic positive-test specimens were negative by RT-PCR that was possibly caused by low detection level of the assay.

Conclusion The RT-PCR assay is potential to be used for the detection of HIV-1 infection with a sensitivity and specificity of $80.8 \%$ and $95.0 \%$ respectively. (Med J Indones 2010; 19:154-7)
\end{abstract}

Key words: AIDS, diagnosis, PoL, sensitivity, specificity

Acquiredimmunodeficiency syndrome(AIDS) is caused by the human immunodeficiency virus type 1 (HIV-1) that poses the most important concern to the public health worldwide. ${ }^{1-4}$ Laboratory diagnosis for HIV-1 infection by the detection of HIV-1 specific antibody is not possible when the infected individuals fail to produce HIV-1 specific antibodies, ${ }^{5}$ the case is infected by the most divergent HIV-1 strains, ${ }^{6}$ or at early phase of infection where HIV-1 specific antibody is not produced yet. $^{7}$ In addition, seronegativity or immunological dysfunction due to aggressive disease course occurs. ${ }^{8}$ At such conditions, serological diagnosis of HIV-1 infection can yield false negative results, and the results may compromize legal clinical practices, especially in blood transfusion to uninfected recipients.

Moreover, serological assays may also yield false positive results due to cross-reactive affinity of HIV-1 specific antibody to non HIV-1 protein (in antigen detection) and vice-versa (in antibody detection). ${ }^{9,}{ }^{10}$ Therefore, it is important to develop a new technique that is based on nucleic acid detection such as RT-PCR.

Recently we reported a first generation of an in-house RT-PCR for the detection of HIV-1 infection. ${ }^{11}$ In the 
report, we discussed several factors influencing the sensitivity and specificity of RT-PCR assay, including specimen preparation and transport, type of specimen, stage of HIV-1 infection, Gold Standard used, and primer specification and its target. Since nucleotides of the HIV-1 genomes are highly variable among subtypes even among strains in a subtype as well, we decided to focus on the type of primer and its target. The primer sequences were obtained from alignment analysis of gag regions of $300 \mathrm{HIV}-1$ strains.

\section{METHODS}

\section{Specimen preparation}

Forty-six blood specimens were collected from July to August 2005 at voluntary counseling and testing for HIV (VCT) of RSUP Sanglah, Bali. Blood specimens were collected into a vacutainer without EDTA for serologic assay, and with EDTA for RT-PCR assay. Two hours after blood collections, bloods were centrifuged at $2.000 \mathrm{rpm}$ for $10 \mathrm{~min}$. Following centrifugation, plasma (sample for RT-PCR assay) or serum (sample for serologic assay) specimens were stored at $-20^{\circ} \mathrm{C}$ without further freezing and thawing until transported to Jakarta.

Patients in this study showed variable clinical indications: asymptomatic sign (50\%), lung tuberculosis $(10.9 \%)$, chronic gastroenteritis and low weight $(8.7 \%)$, oral candidosis and chronic gastroenteritis (6.5\%), long fever and cough (6.5\%), lung tuberculosis and oral candidosis $(4.3 \%)$, pneumonia $(2.2 \%)$, and toxoplasmosis $(2.2 \%)$.

\section{Plasma transport}

The RT-PCR assay was done in the Department of Microbiology, Faculty of Medicine, University of Indonesia, Jakarta. To avoid the possibility of RNA or viral degradations caused by plasma transportation from Bali to Jakarta, plasmas were transported by means of a special container that has been filled with ice packs. Transport time from Bali to Jakarta took about 4-5 hours, and after arrival of specimen in Laboratory in Jakarta it was immediately stored in $-80^{\circ} \mathrm{C}$ without further freezing and thawing until used.

\section{Viral RNA extraction}

The HIV-1 RNA(s) were extracted and purified by QIAamp Viral RNA Mini Kit (Qiagen ${ }^{\circledR}$ ) according to manufacturer's instruction with twice $40 \mu \mathrm{L}$ elution and each elute was pooled. Finally, RNase inhibitors (10 units) were added into elute and stored at $-20^{\circ} \mathrm{C}$ until used.

\section{RT-PCR}

One-tube RT-PCR reactions were performed by using OneStep RT-PCR kit $\left(\right.$ Qiagen $\left.^{\circledR}\right)$ with reaction composition: 1x OneStep RT-PCR buffer, $2.5 \mathrm{mM}$ $\mathrm{MgCl}_{2}, 1 \mathrm{x}$ Q solution, $400 \mu \mathrm{M}$ each of dGTP, dCTP, dTTP, and dATP, $0.6 \mu \mathrm{M}$ each of forward [5'-CAG CAT TAT AAG GAG CCA C-3'] and reverse [5'TCT GCA GCT TCC TCA TTG ATG G-3'] primers, OneStep RT-PCR enzyme mix, $4 \mu \mathrm{L}$ viral RNA, and nuclease-free water was added until a final volume of $10 \mu \mathrm{L}$. Thermal cycler, the AB Applied Biosystems Gene Amp PCR system was used and the cycles were: reverse transcription for $30 \mathrm{~min}$. at $50^{\circ} \mathrm{C}$, initial PCR activation step for $15 \mathrm{~min}$. at $95^{\circ} \mathrm{C}$, followed by 40 cycles of denaturing for $30 \mathrm{sec}$. at $94^{\circ} \mathrm{C}$, annealing for $30 \mathrm{sec}$. at $56^{\circ} \mathrm{C}$, and extension for $30 \mathrm{sec}$. at $72^{\circ} \mathrm{C}$, and ended by a final extension for $7 \mathrm{~min}$ at $72^{\circ} \mathrm{C}$.

RT-PCR products were analyzed on an $8 \%$ polyacrylamide gel that contained500 $\mu \mathrm{L} 10 \mathrm{x}$ TBE $[0.089 \mathrm{M}$ Tris base, $0.089 \mathrm{M}$ boric acid, 0.02 M EDTA, pH 8.0], $1.350 \mu \mathrm{L}$ of $30 \%$ acrylamide, $3.150 \mu \mathrm{L}$ of destilated water, $25 \mu \mathrm{L}$ of ammonium persulphate (APS), and $2.5 \mu \mathrm{L}$ of TEMED. The results of gel electrophoresis were visually analyzed on ultraviolet light.

\section{Serologic assay}

Fourty-six serum specimens in this study were tested in VCT of Clinic Sanglah General Hospital-Bali by three different rapid test kits i.e. Determine ${ }^{\mathrm{TM}} \mathrm{HIV} 1 / 2$ (Abbott), ImmunoComb ${ }^{\circledR}$ HIV 1\&2 BiSpot (Orgenics), and Serodia ${ }^{\circledR}$ HIV $1 / 2$ (Fujirebio Inc.). The procedures were in accordance with manufacturer's instructions, and HIV-1 positive was defined as serum reactive against two or three rapid test kits.

\section{Data analysis}

Data obtained from RT-PCR assays was compared with serologic assays to obtain the sensitivity and specificity values.

\section{RESULTS}

The RT-PCR assay developed in this study could detect 21 of 26 rapid test-positive specimens (sensitivity: $80.8 \%$ ), and showed 19 negative results of 20 rapid 
test-negative specimens (specificity: 95.0\%) (Table 1). A positive assay was defined by a 115 bp DNA fragment visualized on polyacrilamide gel (Figure 1).

Table 1 . The result of RT-PCR assay compared with commercial rapid tests.

\begin{tabular}{|c|c|c|c|c|}
\hline & & & d Test & \\
\hline & & Reactive & Non Reactive & \\
\hline & Positive & 21 & 1 & 22 \\
\hline RT-PCR & Negative & 5 & 19 & 24 \\
\hline & Total & 26 & 20 & 46 \\
\hline
\end{tabular}

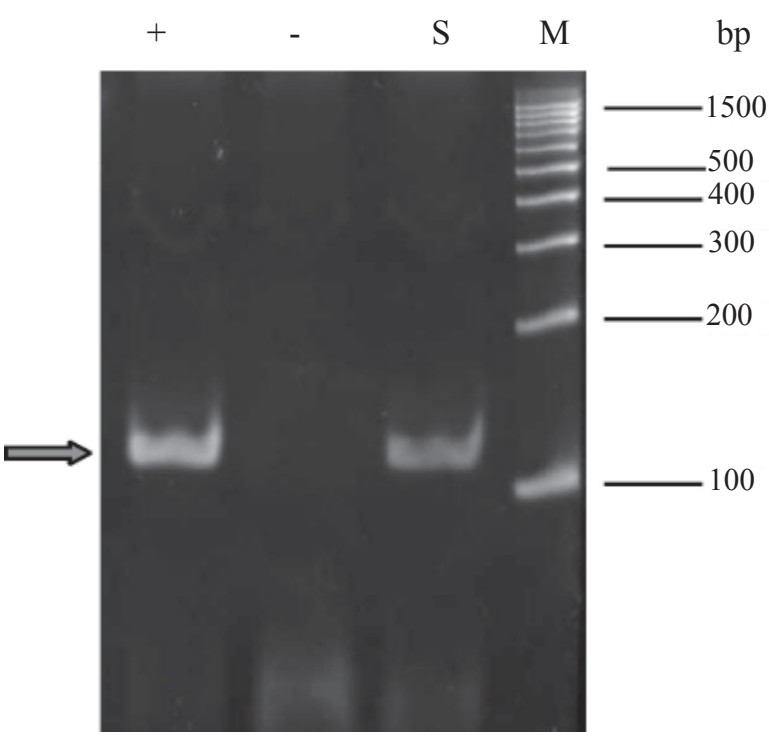

Figure 1. Visualization of RT-PCR results on $8 \%$ polyacrilamide gel stained with ethidium bromide. Lane $M=$ DNA ladder, lane $S=$ patient sample, lane -= negative control, lane $+=$ positive control, $b p=$ base pair.

\section{DISCUSSION}

The technique was unexpectedly able to amplify one of 20 rapid test negative samples (Table 1 ). The result might be true positive as the patients might experience one of following phenomenon: fail to produce HIV-1 specific antibodies, ${ }^{5}$ infection with the most divergent HIV-1 strains, ${ }^{6}$ at early phase of infection, ${ }^{7}$ or immunological dysfunction caused by aggressive disease course. ${ }^{8}$

In addition to false positive result, we also found false negative results. The results may be really negative since the reported serological assays for HIV diagnosis, even commercial rapid test used in this study, yielded false positive results due to cross-reactive affinity between antibody and antigen., ${ }^{9} 10,12,13$ Another reasonable explanation is that the false negative results are the consequence of low RT-PCR sensitivity. It means that a nucleotide amplification technique has a particular level in the capability for detecting its target, and the capability is mainly influenced by the number of viral particles in plasma. Dealing with this, we did not study the sensitivity of the technique in correlation with the number of viral particles or RNA copy number in plasma, but compared with the results of commercial rapid tests.

Comparing previous ${ }^{11}$ to the present assays, both were interestingly different in their sensitivity and specificity. Using the same samples, the previous assay showed false positive results, while the present assay showed false negative result in concordance with the result of commercial rapid test. Such differences also occurred in the positive samples by commercial rapid test. The differences were thought by virtue of the most divergent HIV-1 strains in which a pair of primers could detect particular part of genome sequence, while another pair of primers could not or were not optimal to amplify so that the amplification products could not be detected on gel polyacrilamide by visual means.

At present, there is no report that reveals the influence of opportunistic infections in HIV-1 replication, which in turn affects the sensitivity and specificity of molecular assays. Therefore, we tried to consider the effects of opportunistic infections on the sensitivity and specificity of molecular assays. This issue was based on a study reported by Liu and Hou in which dual infection with hepatitis B virus (HBV) and hepatitis C virus (HCV) could cause suppression of HBV replication by $\mathrm{HCV}^{14}$ In Addition, Jain and colleagues have also compared HIV-1 RNA (viral load) from patients suffering dual infection $\mathrm{HIV} / \mathrm{HCV}$ and $\mathrm{HIV}-1 / \mathrm{HBV}$, and triple infection $\mathrm{HIV}-1 / \mathrm{HBV} / \mathrm{HCV}$; even though effects of HCV or HBV infections on total of HIV-1 RNA were not significant, but among the three groups, dual infection HIV-1/HCV gave the lowest number of HIV-1 RNA. ${ }^{15}$ However, in this study there was no correlation between particular symptoms and the false negative results (data not shown).

In conclusion, the RT-PCR assays were applied for specimens of HIV-1 infected patients with variable clinical symptoms. The RT-PCR techniques with different primers might yield different results for the same specimens. The sensitivity and specificity of the assay in this study was $80.8 \%$ and $95.0 \%$ respectively. As the sensitivity of the previous assay was lower, 
the assay should be followed by the second detection method using oligonucleotide as a probe. further, we are going on a research in developing a dot-blot hybridization technique to improve the technique in order to develop a specific and rapid HIV-1 diagnosis.

\section{Acknowledgements}

This research has been funded by Riset Unggulan Universitas Indonesia (RUUI). We thanks Prof.Dr.dr. K Tuti Parwati, SpPD, Department of Internal Medicine, Faculty of Medicine University of Udayana-RSUP Sanglah, Bali for providing plasma samples.

\section{REFERENCES}

1. Brooks GF, Butel JS, Morse SA, editors. Jawetz, Melnick and Adelberg's medical microbiology. 23rd ed. Boston: McGrawHill; 2004.

2. Fauci AS. HIV and AIDS: 20 years of science. Nat Med. 2003;9:839-43.

3. Harry DJ, Jennings MB, Yee J, Carlson JR. Antigen detection for human immunodeficiency virus. Clin Microbiol Rev. 1989;2:241-9.

4. Murray PR, Rosenthal KS, Kobayashi GS, Pfaller MA. Medical microbiology. 4th ed. St. Louis: Mosby; 2002.

5. Cardoso AR, Goncalves C, Pascoalinho D, Gil C, Ferreira AF, Bartolo I, et al. Seronegative infection and AIDS caused by an A2 subsubtype HIV-1. AIDS. 2004;18:1071-4.

6. Simon F, Mauclere P, Roques P, Loussert-Ajaka I, MullerTrutwin MC, Saragosti S, et al. Identification of a new human immunodeficiency virus type 1 distinct from group M and group O. Nat Med. 1998;4:1032-7.
7. Mylonakis E, Paliou M, Lally M, Flanigan TP, Rich JD. Laboratory testing for infection with the human immunodeficiency virus: established and novel approaches. Am J Med. 2000;109:568-76.

8. Reimer L, Mottice S, Schable C, Sullivan P, Nakashima A, Rayfield M, et al. Absence of detectable antibody in a patient infected with human immunodeficiency virus. Clin Infect Dis. 1997;25:98-100.

9. Fonseca MO, Pang L, de Avila Sdo L, Arruk VG, TozettoMendoza TR, Ferreira AW, et al. Cross-reactivity of antiPlasmodium falciparum antibodies and HIV tests. Trans $\mathrm{R}$ Soc Trop Med Hyg. 2000;94:171-2.

10. Courouce AM, Barin F, Maniez M, Janot C, Noel L, Elghouzzi MH. Effectiveness of assays for antibodies to HIV and p24 antigen to detect very recent HIV infections in blood donors. The Retrovirus Study Group of the French Society of Blood Transfusion. AIDS. 1992;6:1548-50.

11. Yasmon A, Fatmawati NND, Ibrahim F, Parwati KT, Bela B. In-house RT-PCR assay for detection of human immunodeficiency virus type 1 (HIV-1) infection. Makara Seri Kesehatan. 2009;13: 92-4.

12. Zacharias NM, Athanassaki ID, Sangi-Haghpeykar $\mathrm{H}$, Gardner MO. High false-positive rate of human immunodeficiency virus rapid serum screening in a predominantly hispanic prenatal population. J Perinatol. 2004;24:743-7.

13. Mylonakis E, Paliou M, Greenbough TC, Flaningan TP, Letvin NL, Rich JD. Report of a false-positive HIV test result and the potential use of additional tests in establishing HIV serostatus. Arch Intern Med. 2000;160:2386-8.

14. Liu Z, Hou J. Hepatitis B virus (HBV) and hepatitis C virus (HCV) dual infection. Int J Med Sci. 2006;3:57-62.

15. Jain MK, Joshi R, Attar N, Keiser P, Lee W. Comparison of Triple Infection with $\mathrm{HIV} / \mathrm{HBV} / \mathrm{HCV}$ to $\mathrm{HIV} / \mathrm{HCV}$ and HIV/HBV. Southwestern Medical Centre; 2007. Available from: http://retroconference.org/2007/PDFs/933. pdf. (Accessed on 6th Dec. 2007) 